Journal of Community Based Environmental Engineering and Management, 2021, Vol. 5, No. 2: 125-132

\title{
FEASIBILITY STUDY OF JALUPANG WASTE DISPOSAL SITE OF SUBANG REGENCY
}

\author{
Nurcholis Salman* \\ Department of Environmental Engineering, Faculty of Technic, Universitas Muhammadiyah \\ Tasikmalaya, Indonesia
}

\begin{abstract}
The increasing number of residents in Subang Regency every year has a direct impact on the amount of waste generation that must be managed. Until now, Subang Regency only has the Panembong Waste Disposal Site (WDS) in Parung Village which is intended to serve the entire Subang Regency area which includes 30 sub-districts. The Panembong WDS has started operating Since 1991, with the current Open Dumping operational system, the Panembong WDS has experienced an overload on an active land area of $\pm 2.2 \mathrm{Ha}$. The total area of the Panembong WDS is $\pm 6.5 \mathrm{Ha}$ which is used $\pm 1.6 \mathrm{Ha}$ for general landfill infrastructure, the Active Zone of $\pm 2.2 \mathrm{Ha}$ is used as a landfill area and the Passive Zone \pm 2.7 With such conditions, the Subang Regency government proposes and plans to transfer and move the location of the Final Waste Disposal Site (WDS) at the planned location, while the planning location for this WDS is at: Jalupang Village, Kalijati District. The new WDS is planned to use the Sanitary Landfill system, considering that the Open Dumping system is no longer allowed by the government since 2009 which is based on Law No. 18 of 2008 concerning Waste Management. The initial step in the construction of the Sanitary Landfill WDS system is determining the location of the WDS which must comply with the requirements and provisions regarding environmental management, public order, city/environment cleanliness, regional regulations on waste management and urban spatial planning, as well as other implementing regulations that have been determined. by the government. To be able to determine the location of the landfill that meets these requirements. The provisions that must be met to determine the location of the landfill are as follows (SNI number 03-3241-1994).
\end{abstract}

Keywords: Jalupang WDS, Sanitary Landfill, Subang Regency, Waste Disposal Site

\section{Introduction}

The waste problem is one of the urban problems that has been experienced in Indonesia. This problem is inseparable from the lack of balance between the amount of waste generated and the available waste management infrastructure and facilities. Where the amount of waste generated

\footnotetext{
${ }^{*}$ E-mail: nurcholissalman@umtas.ac.id
}

Received: 18 Agustus 2021

Revised: 15 September 2021

Accepted: 18 September 2021

DOI: $10.23969 /$ jcbeem.v5i2.4531 every year continues to increase in proportion to the increase in population, while the growth of infrastructure and facilities is stagnant (slow). Generally, cities in Indonesia have a waste management system with inappropriate handling methods, namely the collect-transport-dispose method. Waste is always identified with waste or worthless waste. Along with higher population growth and a shift in people's lifestyles that are more consumptive, will result in an increasing quantity of waste volume that must be handled. Organic waste (food waste and yard waste) is expected to have been processed 
at the source level or on a communal scale, as well as sorting inorganic waste that can still be recycled (paper waste, plastic waste, metal waste, and glass waste). Final Processing Site (WDS) of waste that uses a landfilling process is a waste processing infrastructure, which is expected to be the final processing of waste in the form of residue only (textile waste, rubber waste, and other waste).

Due to the inadequate handling of waste, it has an impact on the aesthetics of the city which causes the city to look dirty and slum. In addition, this waste also causes water pollution, air pollution (rotten smell) and results in many vectors and germs. In big cities, it is not uncommon for this waste to cause flooding as a result of the blockage of drainage channels and rivers by garbage. As a result of all that, in the end this waste problem has an impact on aspects of public health, socio-economic and sociocultural.

Waste in Subang Regency consists of residential waste, market waste, shopping waste, public facilities waste, educational waste and street sweeping waste. Until now, waste is managed using the Open Dumping method, where waste is only disposed of without being covered with soil or without further processing. This if left unchecked, it will cause disturbance to the environment. These disturbances include, among others, a place for various disease factors to develop, causing odors and dirt and polluting the surrounding water. Therefore, this method does not meet WDS requirements, so a temporary WDS change must be made, namely Open Dumping to a better WDS, namely the Sanitary Landfill method, so that the processing process will be better controlled.

\section{Research Methodology}

This research methodology uses observational research methods by conducting field and institutional surveys. The data required in the form of primary data and secondary data. Primary data were obtained through direct surveys to the field, while secondary data were obtained from government agencies and literature studies. The data is processed and analyzed by scoring, buffering and overlaying methods with the help of a Geographic Information System (GIS). Determination of the location of the landfill refers to the Indonesian National Standard (SNI) number 03-3241-1994 regarding the procedure for selecting the location of the waste landfill.

The selection of a landfill site must have the following provisions:

1. Landfills must not be located in lakes, rivers, and seas.

2. Determination of the location of the WDS is arranged based on 3 stages, namely:

- Regional stage which is the stage to produce a map containing the area or place in the area which is divided into several feasibility zones.

- Elimination stage which is the stage to produce one or two best locations among several selected locations from the feasibility zones in the regional stage.

- Determination stage which is the stage of determining the selected location by the authorized agency.

3. If an area cannot meet the regional stage, the selection of a waste landfill location is determined based on the waste landfill site selection scheme.

\section{Regional Criteria}

Regional Criteria are the criteria used to determine the appropriate or unfeasible zones as follows:

1. Geological Condition

- Not located in the Holocene fault zone (active fault)

- Must not be in the Geological Hazard Zone 
2. Hydrogeological conditions

- Should not have a groundwater level of less than 3 meters

- Ground clearance should not be greater than $10^{-6} \mathrm{~cm} / \mathrm{sec}$.

- The distance to the source of drinking water must be greater than 100 meters downstream of the flow.

- In the event that there are no zones that meet the criteria mentioned above, then technology input must be held.

3. Zone Slope must be less than $20 \%$.

4. The distance from the airfield must be greater than 3000 meters for turbojet flights must be greater than 1500 meters for other types.

5. Not allowed in protected areas / nature reserves and flooded areas with a return period of 25 years.

\section{Elimination Criteria}

The Eligibility Criteria are the criteria used to select the best location, which consists of regional criteria plus the following criteria:

1. Climate

- Rain intensity the less rain the better.

- Wind, the dominant wind direction is not towards settlements is considered to be getting better.

2. Utilities: more complete available is better rated.

3. Biological Environment:

- Habitat: less variety is considered better.

- The carrying capacity of supporting the life of flora and fauna is considered to be getting better.

4. Soil Condition

- Soil productivity: unproductive is rated higher.

- Capacity and age: can accommodate more land and longer is considered better.

- Availability of land cover: having sufficient ground cover is considered better.
- Land status: more varied is considered not good.

5. Demographics: lower population density is considered better.

6. Administrative limits: within administrative limits, it is considered better

7. Noise: the more buffer zones the better.

8. Smell: The more Buffer Zones in the rating the better

9. Aesthetics: The less visible from the outside, the better.

10.Economy: The lower the unit cost of waste management (per $\mathrm{m}^{3} /$ ton) the better.

\section{Determination Criteria}

Determination Criteria are the criteria used by the authorized agency to approve and determine the selected location in accordance with the policies of the local authorized agency and the applicable provisions.

\section{Result and Discussion}

From the preliminary description above that for the determination of the location of this new WDS must be in accordance with the applicable terms and conditions, as for the alternative locations proposed to be the Final Disposal Site in Subang Regency, namely in Jalupang Village, Kalijati District and Cipeundeuy Village, Cipeundeuy District. Previously, Subang Regency had built a Final Disposal Site (WDS), namely Panembong WDS located in Parung Village, Subang District with the following coordinate points:

$\begin{array}{ll}>\text { Latitude } & : 6^{\circ} 35^{\prime} 32.17 " \mathrm{~S} \\ >\text { Longitude } & : 107^{\circ} 44^{\prime} 18.48^{\prime \prime} \mathrm{E}\end{array}$




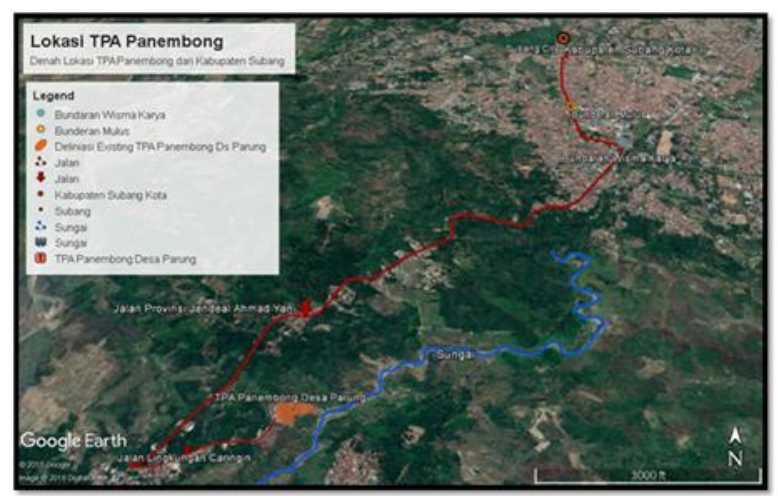

Figure 1. WDS Panembong Location

While the scope of the work of the feasibility study is currently planning for the new WDS which is planned to be located in Cipeundeuy Village, Cipeundeuy District, Subang Regency and Jalupang Village, Kalijati District, as for the image of the location of the planned activity through satellite image maps (google Earth) can be seen in Figure 2 below.

The coordinates for the new WDS plan are: Jalupang Village, Kalijati District.

Latitude : 6 32 '49"S

Longitude : $107^{\circ} 35^{\prime} 19^{\prime \prime} \mathrm{E}$

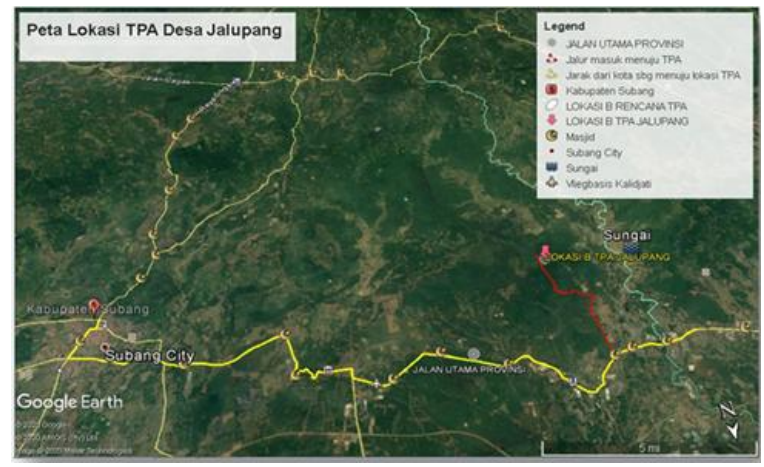

Figure 2. New WDS Location Plan

The area of the WDS planning area in Jalupang Village, Kalijati District for the first stage is \pm 14.8 Ha. For the land status of the location of this WDS development plan, until now the Subang Regency Government has carried out ongoing coordination with the plantation party, in this case PTPN as the authorized agency. in plantation land management. This is because the land that will be used in planning the construction of this WDS facility is on PTPN land.

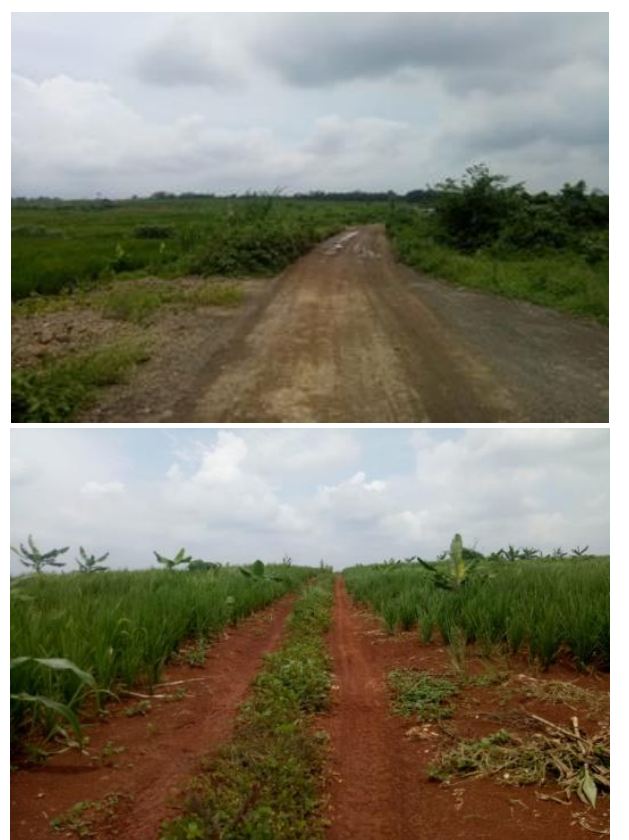

Figure 3. WDS Location in Jalupang Village in Area of Former Sugarcane Plantation

The MOU agreement (Land) from both parties is the basic basis for whether or not the new WDS development planning in Subang Regency is successful, it is hoped that the Subang Regency Government can continue to coordinate and communicate with related parties regarding this land issue. So it is hoped that in the future land problems can be clean and clear and the WDS planning process at the Jalupang Village location can be continued to the next process such as: Environmental Impact Analysisvand other related Environmental Permits (acquisition/land acquisition/land), and others .

After the land, environmental permits, and environmental documents are fulfilled, the planning is included in the Landfill Building Planning along with DED (Design Engineering Details), and finally the implementation of the 
realization of the WDS development in Jalupang Village, Kalijati District, Subang Regency.

The land identification process for the overall WDS development planning (facilities and infrastructure) starting from the road access facilities to the WDS location, other WDS supporting facilities, and up to the WDS development itself, is required to be identified from the pre-planning stage. This is aimed at the next identification process, whether the planning and realization activities will have a direct impact on the land owned by the surrounding community or commonly referred to as Project Affected Persons (PAPs). if the activity has a direct impact on the PAPs, then the local government is obliged to replace the ownership assets of land, buildings, and other assets directly affected by the project activities to be carried out, following applicable laws and regulations. (Regulation of the President No. 62 of 2018 concerning Handling of Social Impacts on Society in the Context of Providing Land for National Development, and other legislation. The following is an analysis to see the strengths or potentials and weaknesses or weaknesses that exist in Jalupang Village, Kalijati District, Subang Regency:

Table 1. Analysis of Landfill Location Determination Criteria

\section{Criteria for Determining the WDS Location Based on SNI Number 03-3241-1994}

Jalupang Village, Kalijati District

\begin{tabular}{|c|c|}
\hline \multicolumn{2}{|l|}{ A. Location Plan } \\
\hline$>$ Lake & The location is not close to the lake \\
\hline$>$ Sea & The location is not close to the sea \\
\hline$>$ River & The location is not close to the river \\
\hline \multicolumn{2}{|l|}{ B. Regional Criteria } \\
\hline \multicolumn{2}{|l|}{$>$ Geology Condition } \\
\hline The location is not in the Holocene fault & The site is not in the Holocene fault \\
\hline Geology danger zone & The location is not in the danger zone \\
\hline \multicolumn{2}{|l|}{$>$ Hydrology Condition } \\
\hline Distance from river $>100 \mathrm{~m}$ & Distance to the river $\leq 100 \mathrm{~m}$ \\
\hline Zone slope $<20 \%$ & $<20 \%\left(0^{\circ}-17^{\circ}\right)$ \\
\hline Distance to the airport $>3000 \mathrm{~m}$ & The location is close to the airport \\
\hline Potential of groundwater levels & Excluding industrial areas \\
\hline Protected areas/nature reserves & $\begin{array}{l}\text { Excluding protected areas/ nature reserves, the location } \\
\text { is on a former sugarcane plantation }\end{array}$ \\
\hline \multicolumn{2}{|l|}{ C. Preliminary Criteria } \\
\hline$>$ Rain intensity (the smaller the better) & $362-487 \mathrm{~mm} / \mathrm{month}$ \\
\hline$>$ Utility & Road access to the location is not good (pavement) \\
\hline \multicolumn{2}{|l|}{$>$ Soil condition } \\
\hline Land productivity & The land is not productive anymore \\
\hline Availability of covered land & $\begin{array}{l}\text { Buffering zones are available, as the land is in the } \\
\text { plantation area }\end{array}$ \\
\hline Land status & $\begin{array}{l}\text { Under the management of Indonesian State Forestry } \\
\text { Company (PTPN) }\end{array}$ \\
\hline
\end{tabular}




\begin{tabular}{|c|c|}
\hline $\begin{array}{l}\text { Criteria for Determining the WDS Location } \\
\text { Based on SNI Number 03-3241-1994 }\end{array}$ & Jalupang Village, Kalijati District \\
\hline \multicolumn{2}{|l|}{$>$ Demography } \\
\hline Distance to settlement & The location is far from the settlement $( \pm 3 \mathrm{~km})$ \\
\hline \multicolumn{2}{|l|}{$>$ Noise } \\
\hline Buffer zone & $\begin{array}{l}\text { Buffering zones are available, as the land is in the } \\
\text { plantation area }\end{array}$ \\
\hline \multicolumn{2}{|l|}{$>$ Smell } \\
\hline Buffer zone & $\begin{array}{l}\text { Buffering zones are available, as the land is in the } \\
\text { plantation area }\end{array}$ \\
\hline \multicolumn{2}{|l|}{$>$ Aesthetic } \\
\hline Not visible from the outside & $\begin{array}{l}\text { Not visible from the outside, but tends to be close to } \\
\text { provincial road access and settlements. }\end{array}$ \\
\hline \multicolumn{2}{|l|}{ D. Assignment Criteria } \\
\hline$>$ Neighborhood & $\begin{array}{l}\text { Includes areas of military development, trade, } \\
\text { urban, plantations, livestock, agricultural people's } \\
\text { forests, housing, and urban areas. } \\
\text { - Excluding water catchment areas } \\
\text { - Development of industrial zones }\end{array}$ \\
\hline$>$ Socialization & Socialization has been done to the people. \\
\hline$>$ Local government policy & $\begin{array}{l}\text { Coordination with relevant agencies regarding the } \\
\text { determination of the location of the new landfill plan }\end{array}$ \\
\hline
\end{tabular}

Table 2. New Landfill Location Parameter Assessment Results

\begin{tabular}{|c|c|c|c|c|}
\hline No & Parameter & Weight & Value & $\mathbf{W} \times \mathbf{V}$ \\
\hline $\mathbf{I}$ & GENERAL & & & \\
\hline \multirow{5}{*}{1} & Administrative Limits & 5 & & \\
\hline & a. Within administrative limits & & 10 & 50 \\
\hline & $\begin{array}{l}\text { b. Beyond administrative limits but in one integrated waste landfill } \\
\text { management system }\end{array}$ & & 5 & \\
\hline & $\begin{array}{l}\text { c. Beyond administrative limits and beyond integrated landfill } \\
\text { management }\end{array}$ & & 1 & \\
\hline & d. Beyond administrative limits & & 1 & \\
\hline \multirow{6}{*}{2} & Ownership of land rights & 3 & & \\
\hline & a. Central local government & & 10 & \\
\hline & b. Personal & & 7 & \\
\hline & c. Private/corporate rights and/or ownership status & & 5 & \\
\hline & d. More than 1 owner of rights and/or ownership status & & 3 & 9 \\
\hline & e. Social/religious organizations & & 1 & \\
\hline \multirow{3}{*}{3} & Land Capacity & 5 & & \\
\hline & a. More than 10 years & & 10 & 50 \\
\hline & b. 5-10 years & & 8 & \\
\hline
\end{tabular}




\begin{tabular}{|c|c|c|c|c|}
\hline No & Parameter & Weight & Value & $\mathbf{W} \times \mathbf{V}$ \\
\hline & c. 3-5 years & & 5 & \\
\hline & d. Less than 3 years & & 1 & \\
\hline \multirow{6}{*}{4} & Number of landowners & 3 & & \\
\hline & a. 1 Family & & 10 & \\
\hline & b. 2-3 families & & 8 & \\
\hline & c. 4-5 families & & 5 & \\
\hline & d. 6-10 families & & 3 & \\
\hline & e. More than families & & 1 & \\
\hline \multirow{4}{*}{5} & Communinty Participation & 3 & & \\
\hline & a. Spontaneously & & 10 & \\
\hline & b. Driven by & & 5 & 15 \\
\hline & c. Negotiations & & 1 & \\
\hline II & PHYSICAL ENVIRONMENT & & & \\
\hline \multirow{4}{*}{1} & Soil (above groundwater) & 5 & & \\
\hline & a. Permeability $<10^{-9} \mathrm{~cm} / \mathrm{sec}$ & & 10 & 0 \\
\hline & b. Permeability $10^{-9} \mathrm{~cm} / \mathrm{sec}$ & & 7 & \\
\hline & c. Permeability $>10^{-6} \mathrm{~cm} / \mathrm{sec}$ unless there is a technological input & & & \\
\hline \multirow{5}{*}{2} & Groundwater & 5 & & \\
\hline & a. $\geq 10 \mathrm{~m}$ with permeability $<10^{-6} \mathrm{~cm} / \mathrm{sec}$ & & 10 & 0 \\
\hline & b. $>10 \mathrm{~m}$ with permeability $<10^{-6} \mathrm{~cm} / \mathrm{sec}$ & & 8 & \\
\hline & c. $\leq 10 \mathrm{~m}$ with permeability $<10^{-6} \mathrm{~cm} / \mathrm{sec}-10^{-4} \mathrm{~cm} / \mathrm{sec}$ & & 3 & \\
\hline & d. $>10 \mathrm{~m}$ with permeability $<10^{-6} \mathrm{~cm} / \mathrm{sec}-10^{-4} \mathrm{~cm} / \mathrm{sec}$ & & 1 & \\
\hline \multirow{4}{*}{3} & Groundwater flow system & 3 & & \\
\hline & a. Discharge area/local & & 10 & \\
\hline & b. Recharge area and discharge area local & & 5 & 15 \\
\hline & c. Recharge area regional and local & & 1 & \\
\hline \multirow{4}{*}{4} & Related to the use of groundwater & 3 & & \\
\hline & a. Possible utilization of groundwater with hydrolysis limits & & 10 & 0 \\
\hline & b. Projected to be utilized with hydrolyse limits & & 5 & \\
\hline & c. Projected to be utilized indefinitely hydrolysis & & 1 & \\
\hline \multirow{4}{*}{5} & Danger of flooding & 2 & & \\
\hline & a. There is no danger of flooding & & 10 & 20 \\
\hline & b. Possibility of flooding $>25$ years & & 5 & \\
\hline & $\begin{array}{l}\text { c. Possibility of flooding }<25 \text { years unless there is a technological } \\
\text { input }\end{array}$ & & 1 & \\
\hline \multirow{4}{*}{6} & Land cover & 4 & & \\
\hline & a. Cover land is enough & & 10 & 40 \\
\hline & b. Cover land is enough until half-time usage & & 5 & \\
\hline & c. There is no land cover & & 1 & \\
\hline \multirow{3}{*}{7} & Rain intensity & 3 & & \\
\hline & a. Under $500 \mathrm{~mm}$ per year & & 10 & \\
\hline & b. Between $500 \mathrm{~mm}-1000 \mathrm{~mm}$ per year & & 5 & 15 \\
\hline
\end{tabular}




\begin{tabular}{|c|c|c|c|c|}
\hline No & Parameter & Weight & Value & $\mathbf{W} \times \mathbf{V}$ \\
\hline & c. Above $1000 \mathrm{~mm}$ per year & & 1 & \\
\hline \multirow{4}{*}{8} & Road to location & 5 & & \\
\hline & a. Flat in good condition & & 10 & 50 \\
\hline & b. Flat in bad condition & & 5 & \\
\hline & c. Not flat & & 1 & \\
\hline \multirow{5}{*}{9} & Waste transport & 5 & & \\
\hline & a. Under 15 minutes from waste centroid & & 10 & \\
\hline & b. Between 16-30 minutes from waste centroid & & 8 & 40 \\
\hline & c. Between 31-60 minutes from waste centroid & & 5 & \\
\hline & d. More than 60 minutes from waste centroid & & 1 & \\
\hline \multirow{4}{*}{10} & Entrance road & 4 & & \\
\hline & a. Waste trucks don't go through settlements & & 10 & \\
\hline & b. Waste trucks through medium-density settlements $(\leq 300 \mathrm{pp} / \mathrm{Ha})$ & & 5 & 20 \\
\hline & c. Waste trucks through medium-density settlements $(>300 \mathrm{pp} / \mathrm{Ha})$ & & 1 & \\
\hline \multirow{5}{*}{11} & Traffic & 3 & & \\
\hline & a. Located $500 \mathrm{~m}$ from public roads & & 10 & 30 \\
\hline & b. Located $<500 \mathrm{~m}$ from low traffic & & 8 & \\
\hline & c. Located $<500 \mathrm{~m}$ from medium traffic & & 5 & \\
\hline & d. Located on high traffic & & 1 & \\
\hline \multirow{4}{*}{12} & Land use & 5 & & \\
\hline & a. Has little impact on the use of surrounding soil & & 10 & \\
\hline & b. Has medium impact on the use of surrounding soil & & 5 & \\
\hline & c. Has high impact on the use of surrounding soil & & 1 & 5 \\
\hline \multirow{4}{*}{13} & Farm & 3 & & \\
\hline & a. Located on unproductive land & & 10 & \\
\hline & b. There is no impact on the surrounding agriculture. & & 5 & \\
\hline & c. Has a major impact on the use of surrounding soil & & 1 & 3 \\
\hline \multirow{4}{*}{14} & Protected areas/nature reserves & 2 & & \\
\hline & a. There are no protected areas/nature reserves around it & & 10 & 2 \\
\hline & $\begin{array}{l}\text { b. There are protected areas/nature reserves around it that are not } \\
\text { negatively affected }\end{array}$ & & 1 & \\
\hline & $\begin{array}{l}\text { c. There are protected areas/nature reserves around it that are } \\
\text { negatively affected }\end{array}$ & & 1 & \\
\hline \multirow{4}{*}{15} & Biological & 3 & & \\
\hline & a. Low habitat value & & 10 & 30 \\
\hline & b. High habitat value & & 5 & \\
\hline & c. Critical habitat & & 1 & \\
\hline \multirow{4}{*}{16} & Noise and Smell & 2 & & \\
\hline & a. There is a buffer zone & & 10 & 20 \\
\hline & b. There is a limited buffer zone & & 5 & \\
\hline & c. There is no buffer zone & & 1 & \\
\hline 17 & Aesthetic & 3 & & \\
\hline
\end{tabular}




\begin{tabular}{|c|c|c|c|c|}
\hline No & Parameter & Weight & Value & $\mathbf{W} \times \mathbf{V}$ \\
\hline & a. Protection operations are not visible outside & & 10 & 30 \\
\hline & b. The protection operation looks a little from the outside. & & 5 & \\
\hline & c. Protective operations visible from the outside & & 1 & \\
\hline
\end{tabular}

With a total of 447 points, for parameter assessment and physical location planning in Jalupang Village, Kalijati District, it can be said that it is feasible to be used as a new WDS location planning in Subang Regency.

\section{Subang Regency Geophysical Conditions}

\section{Geology}

The study of the geological conditions of Subang Regency is based on data from the results of previous investigations by the geological research and development center (PPPG) of the Geological Directorate of the Department of Mining and Energy in 1978. The geology of the northern coast of Subang Regency is formed by four sediment units, namely:

- Deposits of tuffaceous sandstone, sandstone, sand and tuffaceous silt. Forming a broad plain of weak waves, moderate to high graduation, especially in sandstone weathering found in the Ciasem, Batanggede and surrounding areas.

- River Sediment Alluvium, generally composed of fine-grained materials (silt clay with sand inserts) and coarsegrained materials (sand and gravel), low to high graduations are found in the eastern part of the Pusakanagara area.

- Alluvium of medium to fine grained plain deposits consisting of sand and clay with sandy inserts, medium graduation, most of the northern coastal area of Subang Regency is formed by alluvium of this plain deposit.

- Silt, sand, gravel covered with clay were found in the northern part of Pangarengan village.

As for Geology, the soil type in Jalupang Village, Kalijati District, is mostly composed of rock types:

- Yellowish-red podsolik, and

- Latosol - andosol.

The soil bearing capacity in the planning location of the WDS Jalupang Village, Jalupang District as a whole is red soil with a podzolic type (yellowish red soil type). The characteristics of this soil type are soils that are formed due to high rainfall and very low temperatures and are also old mineral soil types that have a yellowish or reddish color. The color of this podzolic soil indicates a relatively low level of soil fertility due to leaching. The yellow and red colors are caused by oxidized lumps of iron and aluminum. The clay minerals found in this soil are dominated by silicates. Soil types are Latosol and Andosol in most of the Kalijati District, generally the type of soil is latosol. The characteristics of latosol or inceptisol soil are as follows:

○ Has a rather thick to thick soil solum, which is from about $130 \mathrm{~cm}$ to more than 5 meters.

- The soil is red, brown, to yellowish

o Soil texture in general is clay 
- The soil structure in general is crumb with a loose consistency

- Has a pH of 4.5 to 6.5 , i.e. from acidic to slightly acidic

- It has about $3 \%$ to $9 \%$ organic matter, but in general it is only $5 \%$

- Contains moderate to high nutrients. Nutrients contained in the soil can be seen from the color. The redder the color of the soil, the less nutrients it contains.

- Has a rather fast to rather slow infiltration

- The power of the homeland is quite good

Technically in terms of soil type, the WDS location planning in Jalupang Village, Kalijati District can meet technical feasibility.

Geomorphology

Judging from the topography, Subang Regency can be divided into 3 (three) regional zones, namely;

1) Mountain Area

This area has an altitude between 500 $1500 \mathrm{~m}$ above sea level with an area of $41,035.09$ hectares or $20 \%$ of the entire area of Subang Regency. This area includes Sagalaherang District, most of Jalancagak District, most of Cisalak District and most of Tanjungsiang District.

2) Wavy/Hilly Area

Areas with an altitude between 50 $500 \mathrm{~m}$ above sea level with an area of $71,502.16$ hectares or $34.85 \%$ of the total area of Subang Regency.

3) Lowland Area

With a height between $0-50 \mathrm{~m}$ above sea level with an area of 92,639.7 hectares or $45.15 \%$ of the entire area of Subang Regency. This is the north coast region (North Coast) covering the Districts of Pagaden, Cipunagara, Compreng, Ciasem, Pusakanagara, Pamanukan, Legonkulon, Blanakan, Patokbeusi, a small part of Cikaum District and a small part of Purwadadi District. When viewed from the level of land slope, it is noted that $80.80 \%$ of Subang Regency has a slope of $0^{\circ}$ $17^{\circ}, 10.64 \%$ with a slope of $18^{\circ}-45^{\circ}$, while the rest $(8.56 \%)$ has a slope above 450 .

The area includes Cijambe District, Subang District, Cibogo, Kaljati, Cipeundeuy, Most Purwadadi and Cikaum Districts.

\section{Conclusion}

The regional stage is the initial stage in determining the location of the WDS, which is intended to reduce the observation area in the study area. At this stage, two zones are obtained, namely the feasible zone and the unfeasible zone. The determination of the regional suitability zone is carried out by overlaying the physical parameters which are the basis for the requirements for determining the location of the landfill. The physical parameters are the slope, lithology, and the potential of the groundwater table and meet the limiting factors.

Judging from the description above regarding the analysis of determining the location of the new WDS planning in Subang Regency, from these points it can be concluded that for a good and proper planning location it is in Jalupang Village, Kalijati District.

\section{Acknowledgment}

With the implementation of CS activities in PAS Company, the team expressed its gratitude to Trisakti University for financing this activity, to 
the Department of Mining Engineering and the Faculty of Earth and Energy Technology for the support that has been given and to PAS Company has given the CS team the opportunity to do this activity and there is a flexibility to discuss and share experiences.

\section{References}

Kawung, E.J. R., dan Tamod, Z.E. (2009). Tingkat Kelayakan Lahan WDS Sampah Kota Manado Dalam Ukuran Mitigasi Perencanaan Lokasi TPA. Jurnal EKOTON, 9 (1): 1-10

Oktariadi, O. (2010). Penentuan Zona Kelayakan TPA Sampah Berdasarkan
Aspek Geologi Lingkungan Di Wilayah Provinsi Banten. Makalah Sosialisasi Geologi Lingkungan Untuk Penataan Ruang Provinsi Banten

SNI 03-3241-1994. TATA CARA PEMILIHAN LOKASI TPA. Departemen Pekerjaan Umum,

Peraturan Daerah Kabupaten Subang No. 3 Tahun 2014. Rencana Tata Ruang Wilayah Kabupaten Subang Tahun 20112031. Subang, Jawa Barat.

Kabupaten Subang dalam angka (Subang District in Figures). (2019). Badan Pusat Statistik Kabupaten Subang. 